pemaparan mengenai relasi antarmanusia dari sudut teologis, pemikiran filsuf-teolog Søren Kierkegaard banyak sekali digunakan. Di satu sisi, kehadiran begitu banyak pemikir dalam buku ini dapat membuat pembaca kewalahan dalam memahami isinya. Di sisi lain, hal ini justru dapat dilihat sebagai salah satu kekayaan buku ini, yang dapat membuka wawasan pembaca dan mengajaknya untuk lebih mendalami pemikiran tokoh tertentu sesuai dengan minatnya. Seluruh studi ini membawa pengarang kepada kesimpulan bahwa hakikat sosialitas manusia tidaklah dapat dipahami hanya dengan membandingkannya dengan sosialitas hewan, sebagaimana biasanya dilakukan. Pada akhirnya, hakikat kemanusiaan, termasuk sosialitasnya, akan tersingkap dalam relasi dan interaksi konkret antarmanusia, entah bersifat positif atau negatif. Hanya dengan demikian kita akan memahami siapakah diri kita yang sesungguhnya sebagai manusia. (Thomas Hidya Tjaya, Program Studi Ilmu Filsafat, Sekolah Tinggi Filsafat Driyarkara, Jakarta).

Gerardette Philips, Beyond Pluralism: Open Integrity as a Suitable Approach to Muslim-Christian Dialogue, Yogyakarta: Institut DIAN/Interfidei, 2013,

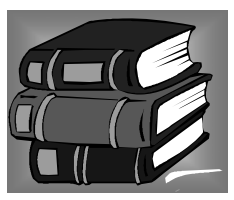
$\mathrm{xx}+228 \mathrm{hlm}$.

Buku ini berawal dari sebuah disertasi yang ditulis Sr. Gerardette Philips, RSCJ, pengarangnya, untuk meraih gelar doktor di bidang Ilmu Filsafat di Sekolah Tinggi Filsafat Driyarkara, Jakarta. Penerbitannya menjadi sebuah buku oleh Interfidei - sebuah Penerbit di Indonesia yang menaruh perhatian khusus pada persoalan dialog antaragamasungguh layak disambut baik. Penerbitan buku ini dalam bahasa Inggris memiliki segi negatif maupun positifnya tersendiri. Segi negatifnya, hal itu membuat jumlah publik pembacanya di Indonesia lebih terbatas pada mereka yang dapat memahami bahasa Inggris. Jumlahnya jelas jauh lebih sedikit dibandingkan dengan jumlah pembaca buku ini kalau ditulis dalam bahasa Indonesia. Walaupun demikian, segi positifnya, dengan diterbitkannya dalam bahasa Inggris, publik pembaca yang dapat 
mengaksesnya secara internasional menjadi lebih banyak. Apalagi buku ini juga memuat Kata Pengantar dalam bahasa Inggris dari Prof. Seyyed Hossein Nasr, seorang tokoh Muslim yang hendak ditampilkan pengarang buku ini sebagai pemikir sekaligus pelaku dialog Muslim-Kristen yang melampaui pendekatan pluralisme. Tokoh dari pihak agama Kristen yang ditampilkan oleh pengarang adalah Hans Küng.

Selama ini banyak orang beranggapan bahwa pluralisme merupakan paham hubungan antaragama, yang memiliki bentuk pendekatan yang paling tepat dalam melakukan dialog antaragama, termasuk di dalamnya dialog antara umat Muslim dan Kristen. Memang, dibandingkan dengan pendekatan eksklusivisme maupun inklusivisme, seperti ditegaskan oleh pengarang buku ini (hlm. 1; 60-63; 67), pluralisme memiliki kelebihan tersendiri. Namun, pluralisme mengandung beberapa kelemahan yang layak dikritik. Paling tidak ada tiga kelemahan pokok dari pendekatan pluralisme yang dicoba ditunjukkan dalam buku ini. Pertama, pluralisme mengandung bahaya tidak mengambil serius identitas keagamaan yang khas dan berbeda untuk setiap agama karena ingin menekankan keselarasan antara semua agama, agar tidak terjadi konflik antara pemeluk agama yang berbeda. Guna menguatkan pendapatnya, pengarang mengutip pernyataan Paul Knitter (hlm. 64) yang berbunyi: "Karena begitu terpesona oleh keindahan sebuah simfoni, kaum pluralis melupakan perbedaan dan kekhasan dari masing-masing alat musik yang dipakai." Pendekatan pluralisme juga mengandung bahaya jatuh ke dalam relativisme, karenaterdorong oleh kehendak untuk mau bersikap terbuka terhadap penganut agama yang lain dan mau menghormati perbedaan keyakinan merekapara pluralis lalu cenderung merelatifkan klaim kebenaran agamanya sendiri. Tanpa harus menjadi seorang eksklusivis - yang memutlakkan klaim kebenaran keyakinan agamanya sendiri seraya menganggap sesat keyakinan agama yang lain-keseriusan untuk sungguh meyakini kebenaran iman agama yang dipeluknya, sangat diperlukan dalam berdialog agar tidak menjadi kompromistis dan jatuh ke dalam relativisme. Sikap terbuka terhadap para pemeluk agama yang lain - yang berbeda dengan agamanya sendiri-memang diperlukan dalam sebuah dialog 
antaragama yang sejati. Namun, hal itu perlu dilakukan tanpa kehilangan jatidirinya sendiri sebagai pemeluk agama tertentu yang diyakini kebenarannya. Kelemahan ketiga dari pluralisme adalah bahaya menjadi imperialis tanpa disengaja. Kembali mengutip pernyataan Knitter (hlm. 68), pengarang menyebut adanya dua kemungkinan seorang pluralis yang berniat baik tanpa disengaja menjadi seorang imperialis. Pertama, dengan terlalu cepat seorang pluralis menarik kesimpulan tentang adanya suatu dasar pijak atau platform yang sama dari macam-macam agama yang ada yang dapat mempersatukan semuanya. Kedua, ia dengan terlalu mudah merumuskan panduan umum bersama untuk melakukan dialog antaragama-agama yang berbeda.

Adapun bentuk pendekatan dalam berdialog antaragama - khususnya antara umat Muslim dan umat Kristen yang menjadi fokus perhatian dalam buku ini-yang oleh pengarang dianggap lebih tepat dan dapat mengatasi kelemahan pendekatan pluralisme di atas, adalah apa yang ia sebut open integrity. Yang dimaksudkan adalah bahwa si pelaku dialog memiliki sikap terbuka terhadap pemeluk agama yang lain dengan sungguh mau mendengarkan dan memahami apa yang diyakini oleh yang lain. Ia berusaha menjalin komunikasi yang mendalam dengan pemeluk agama lain dengan berusaha secara tulus bertanya bila tidak tahu dan tidak paham. Ia juga berusaha terbuka terhadap pertanyaan dan kritik dari pihak pemeluk agama lain yang dengan tulus ingin mencari tahu dan memahami apa yang ia yakini sebagai benar. Sikap terbuka juga diarahkan pada kenyataan adanya perbedaan dalam ajaran masingmasing agama yang tidak selalu dapat didamaikan satu sama lain. Sikap terbuka ini juga diwujudkan dalam sikap menghormati perbedaan dan menghargai keunikan masing-masing. Tetapi dengan menggunakan pendekatan open integrity, pelaku dialog yang sejati juga tetap menjaga integritas dirinya sebagai pemeluk agama tertentu yang sungguh ia yakini kebenarannya tanpa perlu mengkompromikan dengan yang lain guna merelatifkan perbedaan yang ada di antara mereka (hlm. 8). Keselarasan hidup bersama dicari dan diupayakan perwujudannya tanpa mengorbankan identitas khas masing-masing. Menghayati imannya sendiri secara 
mendalam tidak membuat orang menutup diri terhadap penghayatan iman yang berbeda dengan dirinya. Sebaliknya, justru dapat membuat orang menjadi sadar akan keagungan Allah yang mengatasi batas-batas kotak organisasi keagamaan yang ia anut. Menurut pengarang buku ini, sikap memelihara keterbukaan terhadap penganut agama yang lain seraya menjaga integritas diri dalam keyakinan imannya sendiri, membuat orang beragama dapat tetap berakar dalam keyakinan imannya dan sekaligus dapat memahami dan menjalin hubungan yang mendalam dengan mereka yang beriman lain (hlm. 238).

Sebagai kerangka pemikiran dan model praksis berdialog antara umat Muslim dan umat Kristen dengan pendekatan open integrity, pengarang merujuk pada pemikiran dan praksis berdialog Seyyed Hossein Nasr dan Hans Küng. Nasr dari sisi umat Muslim, sedangkan Küng dari sisi umat Kristen. Bab II buku ini-yang memuat riwayat hidup kedua tokoh tersebut-dimaksudkan oleh pengarang untuk menunjukkan bagaimana, baik Küng maupun Nasr, menghayati dalam peziarahan hidup dan karir intelektual mereka, sikap dialog yang terbuka terhadap yang lain tanpa kehilangan integritas mereka sebagai pemeluk agama Kristen dan Islam yang tidak perlu diragukan komitmennya. Bab III buku berisi ulasan selayang pandang atas tiga bentuk pendekatan dialog antaragama yang secara tradisional diambil, yakni pendekatan eksklusivis, inklusivis dan pluralis. Sedangkan Bab IV (tentang Küng) dan bab V (tentang Nasr) masing-masing berisi ulasan tentang karya dan kegiatan dua tokoh tersebut yang mau ditampilkan pengarang sebagai pemberi inspirasi dan teladan dalam melakukan dialog MuslimKristen dengan memakai pendekatan open integrity. Dalam pandangan pengarang, sumbangan khas pemikiran Nasr bagi pengembangan dialog antaragama, khususnya dialog Muslim-Kristen, terumuskan dalam pembelaannya terhadap tradisi Philosophia Perennis dalam memahami kesatuan hakiki dari macam-macam agama yang ada di dunia dengan perbedaan dan identitasnya yang khas untuk masing-masing. Dalam perspektif Sufisme, Nasr memahami macam-macam agama di dunia sebagai keragaman bentuk yang bersifat eksoterik, tetapi hakikat 
semuanya secara esoteric adalah satu, bersumber pada Allah yang satu, yang menjadi sumber pewahyuan universal dan sumber dari segala sesuatu. Secara khusus terkait dengan dialog Muslim-Kristen, pengarang menunjukkan upaya nyata yang ditempuh Nasr untuk mengembangkan dialog yang serius antara keduanya dengan "menghindari sekedar diplomasi sopan yang sengaja melewatkan persoalan-persoalan mendasar menyangkut kebenaran dan kesalahan" (pernyataan Nasr sebagai tanggapan terhadap makalah Hans Küng tentang dialog Kristen-Muslim yang dikutip pengarang pada hlm. 151).

Menurut pengarang, sumbangan khas Küng pada upaya dialog Muslim-Kristen tercermin dalam upayanya mengembangkan Global Ethic sebagai sarana penting mewujudan perdamaian dunia. Upaya itu mendapat dukungan dari "Parlemen Agama-agama Sedunia" dalam pertemuannya di Chicago pada 1993. Pernyataan Küng yang terkenal mengantar bukunya Global Responsibility dikutip oleh pengarang pada halaman 74. Pernyataan itu berbunyi: "Keberlanjutan hidup manusia di dunia tidak akan terwujud tanpa adanya etika yang bersifat mendunia. Tidak akan ada perdamaian di dunia tanpa perdamaian antaragama. Tidak akan ada perdamaian antaragama tanpa dialog antaragama." Dalam rangka memenuhi tuntutan dasariah untuk memperlakukan setiap manusia secara manusiawi, Küng menekankan empat hal penting yang perlu diwujudkan bersama, yakni (1) bersikap anti kekerasan dan menghormati kehidupan; (2) mewujudkan solidaritas dan menciptakan tatanan ekonomi yang adil; (3) bersikap toleran dan hidup yang jujur; (4) perlunya kesetaraan gender dan kerja sama antara laki-laki dan perempuan (hlm. 76).

Kendati kerangka berpikir yang dipakai oleh Nasr dan Küng dalam menanggapi tantangan agama-agama di dunia dewasa ini menghadapi arus sekularisme yang semakin kuat di Barat dan berbagai bentuk konflik penuh kekerasan yang mengatasnamakan agama di berbagai tempat di dunia, tidak dapat disamakan dan dibandingkan begitu saja, namun pengarang buku ini nampaknya cukup berhasil menampilkan keduanya sebagai orang yang memiliki sumbangan besar dalam upaya mengembang- 
kan dialog antargama pada umumnya dan dialog Muslim-Kristen pada khususnya, dengan memakai pendekatan yang melampaui pluralisme. Sebuah dialog antaragama yang sungguh terbuka terhadap keyakinan yang berbeda dari agama yang lain, mau mendengarkan dan belajar dari yang lain, dengan tetap mempertahankan identitas keagamaan masingmasing. Apakah label pluralis dengan demikian lalu tidak dapat dikenakan pada kedua tokoh itu, kiranya tinggal apa yang dimaksudkan dengan istilah tersebut. Kalau yang dimaksudkan hanyalah bahwa kaum pluralis tidak hanya menerima adanya banyak agama di dunia ini yang berbeda satu sama lain, tetapi juga mengakui bahwa masing-masing memiliki kebenarannya sendiri yang patut dihargai dan dihormati oleh pemeluk agama yang lain, tanpa sendiri harus menyetujuinya, kiranya keduanya juga dapat disebut pluralis. Buku A. Aslan, Religious Pluralism in Christian and Islamic Phiosophy, Japan Society Publications, 1994, yang juga disebut oleh pengarang dalam daftar kepustakaannya, jelas menggolongkan Nasr dalam kelompok pluralis.

Salah satu kelemahan buku ini - sebagai sebuah buku yang dimaksudkan untuk dibaca oleh publik pembaca umum - adalah bahwa formatnya masih mempertahankan format aslinya sebagai sebuah disertasi dan belum cukup diolah untuk dijadikan buku yang lebih dapat diakses dan lebih enak dibaca oleh publik pembaca umum. Bahkan di dalamnya masih dapat ditemukan kata "disertasi" dan belum diganti dengan kata "buku" (lihat hlm. 11). Semboyan dalam bahasa Latin "Extra Ecclesiam Nulla Salus," artinya "Di luar Gereja tidak ada keselamatan," yang dalam teks asli disertasi salah ditulis "Extra Ecclesiam Nulla Sales!" masih terulang kesalahannya dalam buku ini (lihat hlm. 90).

Lepas dari kelemahan kecil di atas, penerbitan buku ini sekali lagi sungguh layak dihargai dan jelas menambah khasanah intelektual yang dapat memperkaya wawasan maupun memberi inspirasi yang berguna bagi siapa saja yang bermaksud mengembangkan dialog antaragama pada umumnya dan khususnya dialog Muslim-Kristen yang menjadi fokus perhatian dalam buku ini. Sr. Gerardette Philips, RSCJ, Ph.D., penulis buku ini, bukan hanya menjadi seorang akademikus yang telah 
meneliti pemikiran Hans Küng dan Seyyed Hosein Nasr, tetapi ia sendiri sudah cukup lama terlibat dalam upaya mengembangkan dialog MuslimKristen. Beliau bahkan sempat menjadi anggota tim penasihat Paus Benedictus XVI dalam Komisi Kepausan dalam Bidang Hubungan dengan Islam. Pengalamannya yang cukup banyak dalam mewujudkan dialog hidup antara umat Islam dan umat Katolik jelas ikut memperkaya wawasan dalam buku ini. (J. Sudarminta, Program Pascasarjana, Sekolah Tinggi Filsafat Driyarkara, Jakarta).

\section{Juliet B. Schor, Plenitude: The New Economics of True Wealth, New York: The Penguin Press, 2010, $258 \mathrm{hlm}$.

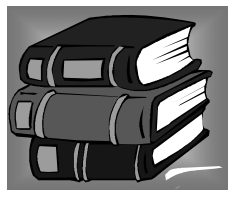

Kehancuran lingkungan ekologis yang makin dirasakan dan disadari banyak pihak akhir-akhir ini telah menimbulkan gelombang perbincangan yang makin memanas, seiring dengan makin panasnya suhu bumi ini. Perbincangan tidak hanya ada pada masyarakat yang langsung terkena dampak kehancuran itu. Sekarang perbincangan itu hampir ada di semua lini sosial, mulai dari hiruk-pikuknya sidang-sidang Perserikatan Bangsabangsa sampai ke warung kopi.

Topik yang sering dibicarakan pada umumnya adalah upaya untuk mengurangi dampak kehancuran itu. Di antara topik-topik itu, yang paling panas diperbincangkan, didiskusikan dan diperdebatkan adalah bagaimana sistem ekonomi berperan besar dalam kehancuran ekologis tadi. Prinsip profit-motif dalam dunia ekonomi dipandang mewadahi keserakahan manusia, apalagi kalau sistem hukum yang dibangunnya lebih mengarah ke sistem kapitalisme dan neoliberalisme. Dengan kata lain, diskusi ini menyasar pada perbaikan sistem ekonomi beserta perangkat hukumnya.

Dalam konteks diskusi mencari jalan keluar agar ekonomi bisa (kembali) menjadi ekologis, muncul wacana tentang pembangunan yang 